J. Product. \& Dev., 19(1):93 - 99 (2014)

\title{
MITES DWELLING IN NESTS OF THE YELLOW WASP, Polistes gallica L. IN SHARKEIA GOVERNORATE, EGYPT
}

\author{
O.M.O. Mohamed
}

Plant Protection Research Institute, A.R.C., Dokki, Egypt

\begin{abstract}
Ten mite species were recorded dwelling in nests of the yellow wasp, Polistes gallica L. in different localities in Sharkeia Governorate, Egypt. Of these, six species of family Tarsonemidae, one species of Glycyphagidae and one species of Oppiidae. Those species are considered of uncertain feeding habits, they may be fungivorous, phoretic or may be responsible for transmitting certain insect pathogens or plant diseases.

The other two species belongs to the predacious families Raphignathidae and Cunaxidae.

Conclusively, Surveying mites associated with nests of the yellow wasp, P. gallica were studied in different parts in Sharkeia Governorate, Egypt. Ten species were recorded belonging to five families and three suborders. Two major groups according to their feeding habits.
\end{abstract}

Key words: Mites, yellow wasp, Polistes gallica L.

\section{INTRODUCTION}

The yellow wasp, Polistes gallica L. is one of the insect enemies of honey bees, Apis mellifera L.. This relationship attracted the attention to survey mites dwelling in its nests as a primary study to explore that phenomenon and to group them into major categories according to their feeding habits.

Mites associated with insect pests are considered as beneficial organisms when they reduce the pest populations. They (mites) may be harmful when infest the useful insects.

Mostafa (1970) described 28 species of saproglyphid hypopi associated with wasps of the genus Zethus. El- Badry (1971) described the hypopus of Sennertia egyptiaca El-Badry from the acarinarium of the carpenter bee, Xylocopa aestuans Linn.. El- Naggar (1977) studied the relationship between mites and some hymenopterous insects, he recorded 44 mite species from those insects and their nests. El- Duweini (1978) found 38 mite species belonging to 4 suborders in association with hymenopterous 
insects. Yousef and Metwally (1979) described the anoetid mite species, Hististoma cataglyphi Yousef \& Metwally in the nests of the ant, Cataglyphus bicolor Fab. Kandeel (1981) described Metasiteroptes polistesi Soliman \& Kandeel from nests of the yellow wasp, Polistes gallica L. from El- Ismaelia Governorate, Egypt, which was published in Zaher (1986). In 1984, Metwally described 4 species of the genus Scutacarus in the nests of C. bicolor. Gamih (1985) collected 30 mite species belonging to 4 suborders in association with different insect species. Fouly (1988) surveyed the acari association with hymenopterous insects belonging to 22 families. El-Gazzar (1992) collected 42 mite species association with various economic insects.

Therefore, the aim of the present work was mainly to survey mites invalids the nests of the yellow wasp, $P$. gallica in some parts in Sharkeia Governorate, Egypt.

\section{MATERIALS AND METHODS}

Nests of the yellow wasp, $P$. gallica were collected from different parts in Sharkeia Governorate, Egypt around Jan.-Dec., 2013. The nests were placed in plastic bags and transferred to the laboratory. Mites were extracted using Tullgren's funnel, then they were directly mounted in Hoyer's medium, gently heated to have stretched individuals and hasten the clearing process. Lables recording all the necessary informations were stuck on each side of the slides. The collected mites were identified using a research binocular microscope.

\section{RESULTS AND DISCUSSION}

Surveying mites dwelling in nests of the yellow wasp, $P$. gallica in several parts in Sharkeia Governorate, Egypt proved the incidence of ten species belonging to five families and three suborders (Table 1). The suborder Actinedida ranked the highest, either in number of species or in their population. Six species of family Tarsonemidae, a single species from both families Raphignathidae and Cunaxidae.

The tarsonemid species were Tarsonemus pauperoseatus Suski, T. schaarschmiditi Mahunka, T. minusculus Can.\& Fanz., T. pomi Suski, T. noxius Humic. and Pseudotarsonemoides sp. Krantz (1978) stated that the majority of the species of the genus Tarsonemus Can.\&Fanz. are fungivorous or algivorous. Smiley and Landwehr (1976) described Tarsonemus destructor Reuter from Monterey pine, Pinus radiata D. Den in California and they stated that the adults of this mite are predacious on eggs of the false spider mite, Brevipalpus pini Baker and the three spider mites 
Oligonychus subnudus (McGregor), O. milleri (McGregor) and O. cunliffei Pritchard\& Baker. Again, Lindquist and Smiley (1978) established the new genus, Acaronemus for tarsonemid mites predaceous on tetranychoid mite eggs based on the mite, $T$. destructor as the type species.

Table 1: Mites dwelling in nests of the yellow wasp, Polistes gallica L. in Egypt.

\begin{tabular}{|c|c|c|c|}
\hline Suborder, Family & Genus and species & $\begin{array}{r}\text { Feeding } \\
\text { behavior }\end{array}$ & $\begin{array}{l}\text { No. of } \\
\text { individuals } \\
\end{array}$ \\
\hline \multicolumn{4}{|l|}{ Actinedida } \\
\hline \multirow[t]{6}{*}{ Fam. :Tarsonemidae } & 1-Tarsonemus pauperoseatus Suski & uncertain & a \\
\hline & 2- T. schaarschmiditi Mahunka & " & a \\
\hline & 3- T. minusculus Can.\& Fanz. & $"$ & a \\
\hline & 4- T. pomi Suski & " & a \\
\hline & 5- T. noxius Humic. & " & a \\
\hline & 6- Pseudotarsonemoides sp. & $"$ & $\mathrm{a}$ \\
\hline Fam . :Raphignathidae & Raphignathus niloticus Rakha\& Mohamed & predator & $c$ \\
\hline Fam . :Cunaxidae & Cunaxoides zebedielensis Den Hyer & $"$ & c \\
\hline \multicolumn{4}{|l|}{ Acaridida } \\
\hline \multicolumn{4}{|l|}{ Fam . :Glycyphagidae } \\
\hline Oribatida & Glycyphagous geniculatus Vitzthum & Uncertain & $\mathrm{a}$ \\
\hline Fam . :Oppiidae & Oppia sticata Popp & $"$ & $b$ \\
\hline
\end{tabular}

(a): represents high numbers ( not less than 30 individuals/ one nest), (b): represents moderate numbers ( 15-29 individuals/ one nest)and (c): represents few numbers ( 14 or less individuals/ one nest).

The mites, Raphignathus niloticus Rakha\& Mohamed( Fam. Raphignathidae) and Cunaxoides zebedielensis Den Hyer (Fam.Cunaxidae) were recorded in few numbers. Rakha and Mohamed (1980) described $R$. niloticus which was collected in sparrow nests, Giza, Egypt. Smiley (1992) collected C. zebedielensis from Citrus sp., Zebediela Estates, Potgietersrust district, North Trasvaal, South Africa.

The Suborder Acaridida was represented by Glycyphagous geniculatus Vitzthum (Fam. Glycyphagidae) in high number. Hughes (1961) stated that G. geniculatus was found in bird's nests, collected near Slough Bucks, and in grain bin residues. Also, it was found in the nest of a bee, 
Xylocopa ( Koptorthosoma) nigrita F. d'Amani in East Africa. Cooreman (1942) found it in the coffee fruit fly, Ceratitis (Trirhithrum) coffeae Bezzi collected in Java and on a fungus, Polyporus sp. in Sumatra.

The Suborder Oribatida was recorded in moderate numbers by the mite, Oppia sticata Popp ( Fam. Oppiidae). Zaher (1986) stated that $O$. sticata shows wide spread in soil and debris. Also, he gave a note about its biology showing that it feeds on the fungi Aspergillus flavus, A. niger, Penicillium sp., Fusarium moniliform, Rizopus sp. , Rizoctonia solani and Sclerotium rolfsii.

Data indicated that the collected species can be grouped into two major groups according to their feeding habits:

a- Predaceous mites which were represented by $R$. niloticus and $C$. zebedielensis.

b- Mites whose food is uncertain, probably fungivorous or phoretic. Those species were recorded by the tarsonemid representatives $T$. pauperoseatus, T. schaarschmiditi, T. minusculus, T. pomi, T. noxius, Pseudotarsonemoides sp.; G. geniculatus (Fam. Glycyphagidae) and $O$. sticata (Fam. Oppiidae). El-Naggar et al. (1993) stated that some species of the fungus feeders may introduce an exciting in the field of biological control by transmitting certain insect pathogens. On the other hand, some other species of this group may illustrate a drastic picture as they adversely affect the host plant by transmitting several plant diseases.

Al- Mahdawi and Al- Kinani (2011) stated that the red wasp, Vespa orientalis Linn. and the yellow wasp, Polistes olivaceus are hymenoptera insects during Spring and Summer season. Their occurrence increase dramatically during months of July, August and September. These wasps are found in orchards where attach grapes, figs, date and peach. They cause severe damage on both qualities and quantities of fruits. The adults of wasp chew on fruits causing severe injuries that may result in bacterial and fungal infections.

Conclusively, surveying mites associated with nests of the yellow wasp, P. gallica were studied in different parts in Sharkeia Governorate, Egypt. Ten species were recorded belonging to five families and three suborders. Two major groups according to their feeding habits.

\section{ACKNOWLEDGMENT}

The author is grateful to Dr. M. M. H. Kandeel, Professor of Acarology, Faculity of Technology \& Development, Zagazig University, Zagazig, Egypt who kindly identified the mite species and for criticizing the manuscript. 


\section{REFERENCES}

Al-Mahdawi, Q.H.A and M.A. Al-Kinani (2011): Economical damage of the red wasp Vespa orientalis and yellow wasp Polistes olivaceus on grapes. Diyala Agricultural Sciences Journal, 3(2):216-222.

Cooreman, J.(1942): Notes er observations sur les Acariens I. Bull. Mus. Hist. Nat. Belg., 18,33:1-7.

El-Badry,E.A.(1971). Sennertia egyptiaca sp.n.(Acari:Chaetodactylidae), a phoretic mite associated with the carpenter bee, Xylocopa aestuans Linn. Sonder druch aus Bd.69(1):87-90 .

El- Duweini, F. K. (1978): Studies on some mites associated with hymenopterous insects. M. Sc. Thesis, Fac. Agric. , Cairo University: 116pp..

El-Gazzar, H.F. (1992): Studies on some mites associated with insects. M. Sc. Thesis, Fac. Agric. , Al- Azhar Univ., : 109pp..

El- Naggar, M.E. (1977): Survey and biological studies on some mites associated with hymenopterous insects . M. Sc. Thesis, Fac. Agric. , Al- Azhar Univ. : 120pp..

El- Naggar, M.E.; A.M. Mostafa and H.A. Taha(1993): Mites associated with insects in Egypt. Egypt J. Appl. Sci. , 8(12): 502512).

Fouly, A.H. (1988): Studies on some mites associated with insects. Ph. D. Thesis, Fac. Agric. , Mansoura University : 140pp.

Gamih, G.N. (1985): Studies on mites associated with hymenopterous insects. M. Sc. Thesis, Fac. Agric. , Mansoura Univ. : 80pp.

Hughes, A.M. (1961): The mites of stored food. Technical Bulletin No. 9, Ministry of Agriculture, Fisheries and food, London, Her Majesty's Stationery Office: 287pp.

Kandeel, M.M.H. (1981): Ecological and biological studies on some tarsonemid mites. Ph. D. Thesis, Fac. Agric. , Cairo Univ. : 307pp..

Krantz, G.W. (1978): A manual of Acarology. Oregon State Univ. Book Store; Corvallis, Oregon, second edition: 509pp..

Lindquist, E.E. and R.L. Smiley( 1978): Acaronemus, a new genus proposed for tarsonemid mites ( Acari: Prostigmata) predaceous on tetranychoid mite eggs. Can. Ent. 100: 655-662.

Metwally, S.H. (1984): Survey on the family Scutacaridae (Acari) in Egypt. Acarologia, 25(3): 241-248. 
Mostafa, A.I. (1970): Saproglyphid hypopi ( Acarina: Saproglyphidae) associated with wasps of the genus Zethus. Acarologia, 12(3): 566-581.

Rakha, M.A. and M.I. Mohamed (1980): A new Raphignathid mite, Raphignathus niloticus sp. $\mathrm{n}$. from house sparrow nests in Egypt( Actinedida: Raphignathidae). Zag. Univ. Fac. Agric. Res. Bull. No. 206:1-6.

Smiley R.L. (1992): The predatory mite family Cunaxidae ( Acari) of the world, with a new classification. Indira Publishing House, West Bloomfied, Michigan, U.S.A. : 356pp..

Smiley R.L. and V.R. Landwehr (1976): A new species of Tarsonemus (Acari: Tarsonemidae), predaceous on tetranychoid mite eggs. Ann. Ent. Soc. Am. 69: 1065-1072.

Yousef, A.A. and S.A. Metwally ( 1979): Life history of annoetid mite Histiotoma cataglyphi Yousef\& Metwally with describtion of the immature stages. Z. Ang. Entomol. 87: 225-229.

Zaher, M.A.(1986): Survey and ecological studies on phytophagous, predaceous and soil mites in Egypt. ( Nile Valley and Delta). II. predaceous and non- phytophagous mites. PL.480 programme U.S.A. project No. EG- ARS-30, Grant No. FG-EG-139: 567pp.+ Figures, 2799pp.. 


\section{الأكاروسات القاطنة في عشوش الابور الأصفر Polistes gallica L .}

$$
\text { معهد بحوث وقاية النباتاتـ مركز البحوث الزر اعيةـ الدقىـ مصر. }
$$

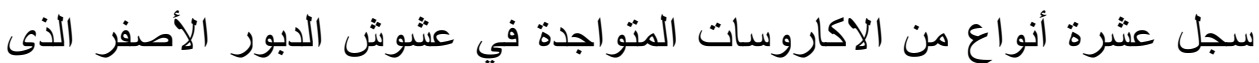

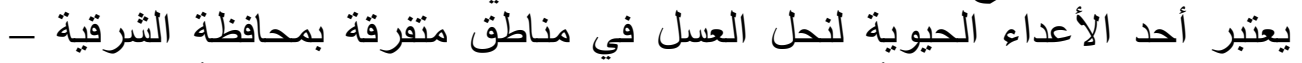

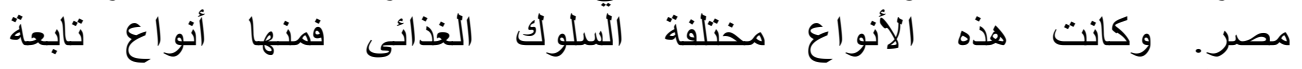
لفصيلة Oppiidae وفصيلة Tarsonemidae وفصيلة Glycyphagidae. تللك الأنو اع التابعة للفصائل السابقة غير معروف سلوكها الغذائي فربما تكون فطرية التغذية أو متنقلة وتكون مسئولة عن نقل مسببات مرضية للحشرات أو أو أمراض فطرية لالنباتات. وقد سجلت أنواع أخرى مفترسة تلعب دورا فى المكافحة الحيوية وهى نوع يتبع فصيلة Cunaxidae. وآخر يتبع فصيلة Raphignathidae.

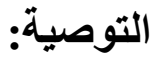

